P-ISSN: 2774-4574; E-ISSN: 2774-4574 TRILOGI, 2(1), Januari-April 2021 (35-52) @2021 Lembaga Penerbitan, Penelitian, dan Pengabdian kepada Masyarakat (LP3M) Universitas Nurul Jadid Paiton Probolinggo DOI: https://doi.org/

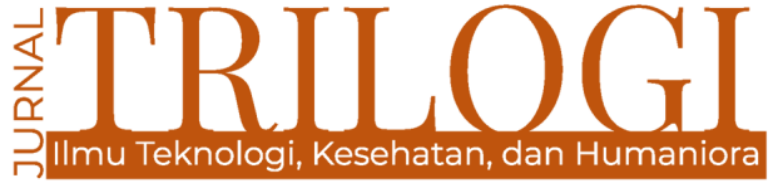

\title{
PEMBELAJARAN JARAK JAUH DAN KEMANDIRIAN BELAJAR SISWA: Tantangan dan Pemecahannya selama Masa Pandemi Covid-19 di Madrasah Aliyah Kholafiyah Hasaniyah Gading Probolinggo
}

\author{
Siti Rohana \\ Universitas Nurul Jadid, Probolinggo \\ sitirohanasr12@gmail.com
}

\begin{abstract}
The research is aim to describe the distance learning implementation of MA Kholafiyah Hasaniyah, its constraint factors, and its impact of the learning to the students self motivated learning. The research method is descriptive qualitative of embedded case study research in order to gather relevan data. Data collection technique is interview, observation, and documentation. The informant is the management, the teachers, and the students of MA Kholafiyah Hasaniyah. The research finding is; (1) There are some paces of distrance learning implementation of MA Kholafiyah Hasaniyah that are training program (preparation), offline learning, online learning, and home visit, and evaluation in the form of formative test, self assignment, amount of tutorial participation, and final/middle examination (PAS/PTS). (2) The constraint factors of MA Kholafiyah Hasaniyah distrance learning implementation are: low students ICT literacy, limited access to the internet, students low in self motivation and achievement, and limited of learning facilities. (3) Distance learning process of MA Kholafiyah Hasaniyah have no sufficient impact to the students self motivated learning, which d by; (a) limited capability of self regulation in learning such as time management, learning strategy, and important critical learning activities as reading, summarizing, note taking is not well programming, (b) low learning responsibility of the students in self evaluation, reflection, problem solving, and regulating learning process, and (c) limited learning resources utilization of the students.
\end{abstract}

Keywords: distance learning; MA Kholafiyah Hasaniyah; student's self-motivated learning

\begin{abstract}
Abstrak
Penelitian ini bertujuan untuk mengetahui pelaksanaan pembelajaran jarak jauh di MA Kholafiyah Hasaniyah, faktor-faktor penghambatnya, serta dampaknya terhadap kemandirian belajar siswa. Penelitian ini menggunakan pendekatan kualitatif deskriptif jenis studi kasus tunggal terpancang (embedded case study research) berusaha menggali sebanyak mungkin fakta sesuai dengan fokus penelitian. Teknik pengumpulan data dengan wawancara, observasi dan dokumentasi melibatkan pengelola, guru, dan siswa MA Kholafiyah Hasaniyah. Hasil penelitian menunjukkan bahwa: (1) Pelaksanaan pembelajaran jarak jauh di MA Kholafiyah Hasaniyah dilakukan melalui beberapa tahap, yaitu pembekalan, pembelajaran tatap-muka, pembelajaran daring, home visit, dan evaluasi belajar yang dilaksanakan dalam bentuk tes formatif, tugas mandiri, Penilaian Akhir dan Tengah Semester (PAS/PTS); (2) Faktor penghambat pembelajaran jarak jauh di MA Kholafiyah Hasaniyah meliputi: literasi digital rendah, keterbatasan akses internet, motivasi belajar dan berprestasi siswa rendah, dan keterbatasan sarana belajar; (3) Pembelajaran jarak jauh terindikasi tidak banyak berdampak pada pembentukan kemandirian belajar siswa, yang dapat dilihat dari (a) dimensi pengelolaan belajar, seperti pengaturan waktu, strategi, dan tempat untuk melakukan aktivitas belajarnya belum tertata, terencana dan terprogram dengan baik, (b) dimensi tanggung jawab belajar, seperti mengatasi kesulitan, indikasi tugas copy paste, mencerminkan tanggung jawab belajar yang masih rendah, dan (c) dimensi pemanfaatan berbagai sumber belajar, seperti pemanfaatan berbagai sumber belajar sangat terbatas.
\end{abstract}

Katakunci: pembelajaran jarak jauh; MA Kholafiyah Hasaniyah; kemandirian belajar siswa 


\section{Pendahuluan}

Pandemi Covid-19 telah mengubah hampir keseluruhan pola pembelajaran di seluruh dunia, termasuk di Indonesia. Menurut The United Nations Educational, Scientific and Cultural Organization (UNESCO), "lebih dari $91 \%$ populasi siswa dunia telah dipengaruhi oleh penutupan sekolah karena Pandemi Coronavirus Disease (Covid-19)" (Strauss, 2020). Di Indonesia sendiri, Kementerian Pendidikan dan Kebudayaan (Kemendikbud) melalui Surat Edaran Mendikbud Nomor 4 Tahun 2020 memberi arahan mengenai belajar dari rumah melalui pembelajaran jarak jauh sebagai upaya untuk memastikan bahwa semua siswa memiliki akses yang sama untuk pendidikan selama masa Pandemi ini (SE Mendikbud 4/2020). MA Kholafiyah Hasaniyah Gading menjadi salah satu sekolah yang juga turut berusaha menerapkan pembelajaran jarak jauh (distance learning) tersebut meskipun terdapat banyak faktor penghambat selama proses pelaksanaannya.

Dalam buku Panduan Pembelajaran Jarak Jauh: Bagi Guru selama Sekolah Tutup dan Pandemi Covid-19 dengan Semangat Merdeka Belajar yang diterbitkan oleh Kemendikbud RI tahun 2020 disebutkan bahwa tujuan pembelajaran jarak jauh antara lain:

1) memberikan pengalaman belajar yang bermakna bagi siswa, tanpa terbebani tuntutan menuntaskan seluruh capaian kurikulum kenaikan kelas maupun kelulusan; 2) memfokuskan pada pendidikan kecakapan hidup antara lain mengenai pandemi Covid-19; 3) memberikan variasi aktivitas dan tugas pembelajaran belajar dari rumah antarsiswa, sesuai minat dan kondisi masing-masing, termasuk mempertimbangkan kesenjangan akses/fasilitas belajar dari rumah; 4) memberikan umpan balik terhadap bukti atau produk aktivitas belajar dari rumah yang bersifat kualitatif dan berguna bagi guru, tanpa diharuskan memberi skor/nilai kualitatif (Tim Penyusun, 2020).

Akan tetapi, keempat tujuan di atas harus dicapai dengan tetap memperhatikan 2 prinsip utama pembelajaran jarak jauh, yakni pertama, tidak membahayakan, bahwa penyampaian kurikulum secara jarak jauh tidak menciptakan lebih banyak stres dan kecemasan bagi siswa dan keluarganya; kedua, realistis, bahwa guru hendaknya memiliki ekspektasi yang realistis mengenai apa yang dapat dicapai dengan pembelajaran jarak jauh, dan menggunakan penilaian profesional untuk menilai konsekuensi dari rencana pembelajaran tersebut.

Berdasarkan tujuan dan prinsip pendidikan jarak jauh yang dirilis oleh Kemendikbud RI tersebut ada beberapa hal yang perlu mendapat perhatian, khususnya bagi para pendidik atau guru. Dalam Poin Nomor 2 dalam Surat Edaran tersebut disebutkan bahwa guru harus membantu siswa menghadapi ketidakpastian yang disebabkan oleh pandemi dan melibatkan siswa untuk terus belajar meskipun kegiatan sekolah terganggu "tanpa harus berfokus pada ketuntasan kurikulum." (SE Mendikbud 4/2020) Kondisi ini mendorong para pemangku kebijakan, utamanya pihak sekolah, berupaya menyediakan fasilitas yang memadai dan memberi pelatihan kepada guru untuk meningkatkan kemampuannya dalam menerapkan sistem pembelajaran jarak jauh saat ini.

Masalahnya, keadaan saat ini masih jauh dari standar. Meskipun Kemendikbud RI, melalui kerjasama dengan berbagai platform telekomunikasi, telah menyediakan fasilitas berupa kuota internet gratis kepada guru dan siswa melalui Surat Edaran Kementerian Pendidikan dan Kebudayaan (Kemendikbud) dengan nomor surat 8202/C/PD/2020 tentang Program Pemberian Kuota Internet bagi Peserta Didik, masih banyak ditemukan guru di berbagai jenjang pendidikan yang belum memiliki kemampuan yang dibutuhkan dalam mendukung siswa selama akses fisik ke sekolah ditutup dan melibatkan siswa dalam bentuk pembelajaran, sehingga konten pembelajaran, kondisi pembelajaran, dan desain pembelajaran selama masa Pandemi dengan baik.

Kondisi tersebut diperparah dengan kenyataan bahwa banyak guru dan siswa yang tidak menerima hak kuota yang seharusnya diberikan. Kuota yang dibeli untuk kebutuhan internet menjadi melonjak dan banyak diantara orangtua siswa yang tidak siap untuk menambah anggaran dalam menyediakan jaringan internet. Koneksi jaringan internet menjadi salah satu kendala yang dihadapi siswa yang tempat tinggalnya sulit untuk mengakses internet, apalagi siswa tersebut tempat tinggalnya di daerah pedesaan, terpencil dan tertinggal, atau pegunungan. Kalaupun ada yang menggunakan jaringan seluler terkadang 
jaringan yang tidak stabil, karena letak geografis yang masih jauh dari jangkauan sinyal seluler. Hal ini juga menjadi permasalahan yang banyak terjadi pada siswa yang mengikuti pembelajaran daring sehingga kurang optimal pelaksanaannya (Yustika, et.al, 2019; Baharun, et.al, 2018).

Hal ini juga diakui sendiri oleh Menteri Pendidikan dan Kebudayaan, Nadiem Makarim, dalam Taklimat Media Penyesuaian Kebijakan Pembelajaran di Masa Pandemi Covid-19 (07/08/2020):

\begin{abstract}
"Prioritas utama pemerintah adalah untuk mengutamakan kesehatan dan keselamatan peserta didik, pendidik, tenaga kependidikan, keluarga, dan masyarakat secara umum, serta mempertimbangkan tumbuh kembang peserta didik dan kondisi psikososial dalam upaya pemenuhan layanan pendidikan selama pandemi COVID-19. Para peserta didik juga mengalami kesulitan berkonsentrasi belajar dari rumah serta meningkatnya rasa jenuh yang berpotensi menimbulkan gangguan pada kesehatan jiwa." (Nadiem Makariem, 07/08/2020)
\end{abstract}

Untuk mengantisipasi hal tersebut, pemerintah menerapkan sistem zonasi pembelajaran. Pemerintah melakukan penyesuaian keputusan bersama Empat Menteri terkait pelaksanaan pembelajaran di zona selain merah dan orange, yakni di zona kuning dan hijau, untuk dapat melaksanakan pembelajaran tatap muka dengan penerapan protokol kesehatan yang sangat ketat. Prosedur pengambilan keputusan pembelajaran tatap muka tetap dilakukan secara bertingkat. Pemda/kantor/kanwil Kemenag dan sekolah memiliki kewenangan penuh untuk menentukan apakah daerah atau sekolahnya dapat mulai melakukan pembelajaran tatap muka (Tim Penyusun, 2020).

Di Probolinggo sendiri, dalam rangka menyikapi kebijakan Kemendikbud tersebut, Dinas Pendidikan (Dispendik) Kabupaten Probolinggo pun menerapkan tiga strategi pembelajaran yang fleksibel, yakni pembelajaran daring, pembelajaran luring, dan pembelajaran campuran daring dan luring. Menurut Kepala Dispendik Kabupaten Probolinggo, Fathur Rozi, tiga pembelajaran tersebut selaras dengan kebijakan Bupati yang tertuang dalam NAWA HATI bidang pendidikan (Wartabromo, 14/10/2020).

Menurut Rozi, pembelajaran daring, diterapkan pada sekolah yang memiliki teknologi informasi dan komunikasi memadai juga jaringan internet yang stabil. Hal itu supaya proses pembelajaran yang memanfaatkan gadget tersebut berjalan lancar. Jika kondisinya tak memungkinkan, maka sistem luring dapat dilakukan. Caranya adalah guru hadir ke komunitas tempat tinggal peserta didik (home visit). Jadi guru-guru itu hadir dan mendatangi peserta didik. Tetapi bukan ke rumahnya, namun ke komunitas tempat tinggal. Sementara itu, untuk strategi proses pembelajaran ketiga adalah pembelajaran campuran. Tetapi ini berlaku bagi yang sudah menerapkan daring dengan memadukan pembelajaran luring untuk mengatasi kejenuhan dan kebosanan peserta didik.

Kecamatan Gading merupakan salah satu zona hijau di Kabupaten Probolinggo sejak status darurat diberlakukan oleh Presiden Jokowi pada awal tahun 2020. Hanya pada Juni 2020, lokasi ini sempat berada di zona kuning dengan 3 ODP dan 8 PDP (menurut Data Covid-19 Kabupaten Probolinggo). Namun, setelah itu, hingga penelitian ini ditulis, kecamatan tersebut sudah berada di zona orange. Menurut data terbaru dari siagacovid19. probolinggokab.go.id per tanggal 13 Juli 2021, terdapat 97 kasus Covid-19 di Kecamatan Gading, dengan rincian 87 sembuh, 3 dirawat, dan 7 meninggal.

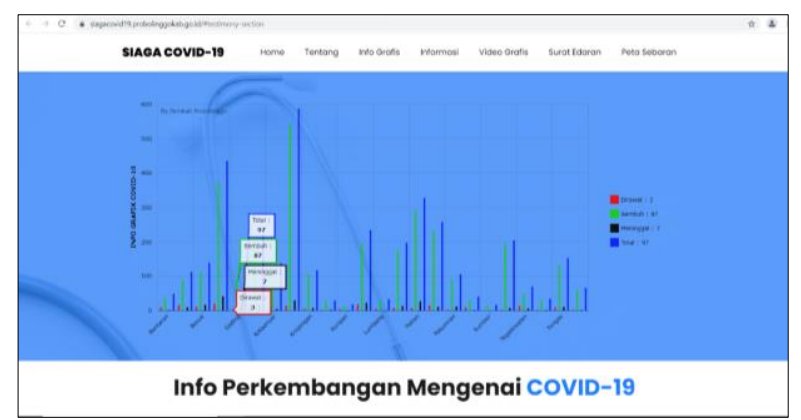

Gambar 1. Infografis Covid-19 di Kabupaten Probolinggo (13/07/2021)

Gambar di atas menunjukkan bahwa Kecamatan Gading termasuk dari lokasi yang bisa dikategorikan aman selama masa Pandemi. Namun, dibanding daerah-daerah dataran tinggi lain, seperti Krucil, Sukapura, Sumber, Tiris, dan Kuripan, Kecamatan Gading termasuk yang memiliki potensi lonjakan kasus Covid-19.

Oleh karena itu, beberapa sekolah di Kecamatan Gading tetap melaksanakan pembelajaran tatap muka, namun sebagian sekolah lain menjaga diri dengan melaksanakan pembelajaran daring, pembelajaran jarak jauh, atau pembelajaran campuran daring dan luring. MA Kholafiyah Hasaniyah yang berada di Kecamatan Gading termasuk salah satu sekolah 
yang menerapkan pembelajaran jarak jauh berbasis daring pada semua materi pelajarannya, kecuali untuk ujian nasional atau ujian akhir sekolah ini menerapkan pembelajaran luring. MA Kholafiyah Hasaniyah juga menerapkan pembelajaran home visit untuk siswa-siswa yang berada di lingkungan atau daerah terdekat. Sebagian materi pelajaran di MA Kholafiyah Hasaniyah juga diajarkan melalui pengerjaan proyek atau tugas berkelompok kecil, utamanya untuk materi-materi pelajaran yang berfokus pada kerajinan tangan atau sejenisnya. Beberapa waktu yang lalu, Ketua Yayasan Kholafiyah Hasaniyah juga meminta masing-masing kepala sekolah di bawahnya untuk memberlakukan penggunaan RPP Daring 1 lembar yang menjadi salah satu kebijakan dari Kemendikbud RI.

Dengan demikian, pemilihan MA Kholafiyah Hasaniyah sebagai konteks penelitian ini didasarkan pada satu kenyataan bahwa sekolah ini dalam beberapa derajat tertentu telah menerapkan sebagian besar kebijakan Kemendikbud RI, mulai dari project based learning, pembelajaran luring dan daring, serta pembelajaran home visit. Penelitian ini akan berfokus pada penerapan pembelajaran jarak jauh di MA Kholafiyah Hasaniyah yang mengkombinasikan sistem luring (syncronous) dan daring (asynchronous). Sebagaimana diketahui bahwa program pembelajaran jarak jauh merupakan pendidikan jarak jauh dengan proses belajar yang dilakukan secara tatap muka langsung/luring (synchronous) dan jarak jauh/daring (asynchronous) (Depdiknas, 2006; Kusuma, et.al, 2020).

Dalam pelaksanaan pembelajaran jarak jauh di MA Kholafiyah Hasaniyah, pembelajaran didahului dengan pertemuan tatap muka (synchronous) atau disebut dengan pembelajaran residensial. Pertemuan residensial ini dilaksanakan di awal semester. Mata pelajaran yang diresidensialkan adalah mata pelajaran akan ditempuh oleh siswa tiap semesternya. Hal ini sebagaimana yang diungkapkan oleh Arif Adinata, S.S., Waka Kurikulum MA Kholafiyah Hasaniyah (10/10/2020):

Semuanya insyallah akan menggunakan daring, dengan media pembelajaran seadanya, seperti WA, Facebook, atau apapun. Tapi, nanti mereka (siswa, red.) itu harus mengikuti semacam pembekalan awal (pertemuan residensial, red.) di awal pertemuan. Guruguru mapel udah kita minta memberikan pembekalan, buat kontrak belajar dengan siswa, dan harus sudah sepakat media apa yang akan digunakan.

Setelah masa residensial selesai, maka pembelajaran di MA Kholafiyah Hasaniyah dilanjutkan dengan pembelajaran jarak jauh (asynchronous) yang mana siswa dan guru pengampu Mapel melakukan proses belajar mengajar tanpa harus berada di ruang dan waktu yang sama. Hal ini sebagaimana yang dikemukakan oleh Eny Wahyuningsih, S.Si., guru Mapel Matematika di MA Kholafiyah Hasaniyah (12/11/2020), "Nanti, mbak, setelah semuanya berkumpul, paling tidak cuma butuh 1-2 pertemuan (residensial, red.), kita dan siswa itu sudah bisa komunikasi lewat daring. Kalau saya, mungkin akan menggunakan Whatsapp." Pelaksanaan pembelajaran jarak jauh di MA Kholafiyah Hasaniyah menggunakan materi ajar berupa modul, namun sebagian besar materinya diperoleh melalui perangkat teknologi informasi dan komunikasi dengan mengakses internet.

Di MA Kholafiyah Hasaniyah sendiri, perangkat teknologi yang paling mungkin digunakan dan paling realistis bagi para siswa adalah media Whatsapp, tentu saja dengan segala kekurangan dan kelebihannya. Sebagian guru juga memanfaatkan CD-Room dan Flashdisk untuk membagikan materi ajar dan penugasan kepada siswa. Media Whatsapp digunakan sebagai media komunikasi antara guru dan siswa dalam pelaksanaan pembelajaran jarak jauh di MA Kholafiyah Hasaniyah, sementara itu CD-Room dan Flashdisk digunakan untuk menyimpan materi pembelajaran yang berbentuk video atau rekaman visual lainnya.

Pada awalnya, MA Kholafiyah Hasaniyah, sebagaimana sekolah-sekolah lain sebelum Pandemi Covid-19, menerapkan pembelajaran tatap muka (luring) seutuhnya. Tetapi, karena Pandemi yang tidak terkontrol ini, sekolah tersebut kini telah mengubah paradigma pembelajarannya menyesuaikan kondisi krisis dengan berbasis pada pembelajaran jarak jauh. Pembelajaran jarak jauh di MA Kholafiyah Hasaniyah dilakukan melalui penggabungan antara luring dan daring sesuai dengan kondisi, waktu, dan kemampuan guru dan siswa. Tentu saja, ada berbagai faktor penghambat yang dirasakan utamanya oleh siswa selama pembelajaran jarak jauh tersebut, misalnya adanya anggapan mudah lulus, kurangnya motivasi belajar sebab tidak adanya kontrol langsung dari guru, merasa tidak memiliki waktu membaca bahan ajar dan materi, serta kesulitan 
memahami bahan ajar (Disarikan dari hasil wawancara dengan beberapa siswa Kelas X MA Kholafiyah Hasaniyah, 11/10/2020).

Adanya perubahan paradigma pembelajaran di atas juga memberi dampak luas pada persiapan, proses, dan evaluasi pembelajaran yang dilakukan oleh guru MA Kholafiyah Hasaniyah dengan berbagai macam faktor penghambatnya. Dari hasil pengamatan awal menunjukkan bahwa penguasaan perangkat teknologi yang menjadi kompunen utama dalam proses pelaksanaan pembelajaran jarak jauh belum sepenuhnya dikuasai oleh guru-guru MA Kholafiyah Hasaniyah. Hal ini sebaagaimana yang disampaikan oleh Arif Adinata, S.S. (10/10/2020), "Rata-rata guru di sini (MA Kholafiyah Hasaniyah, red.), utamanya yang tua-tua, belum bisa mengoperasikan perangkat elektronik dan media sosial, seperti Whatsapp dan Facebook."

Situasi sosial dipilih di lingkungan MA Kholafiyah Hasaniyah karena beberapa pertimbangan, misalnya (1) MA Kholafiyah Hasaniyah termasuk berada di kawasan zona hijau di Kabupaen Probolinggo yang secara prosedural diizinkan untuk melaksanakan pembelajaran luring dan daring; (2) pelaksanaan pembelajaran jarak jauh di MA Kholafiyah Hasaniyah dilakukan dengan proses synchronous dan asynchronous; (3) lokasi rumah para guru dan para siswa MA Kholafiyah Hasaniyah secara geografis memungkinkan adanya berbagai opsi pembelajaran, seperti daring, luring, maupun home visit; (4) MA Kholafiyah Hasaniyah juga baru menerapkan desain pembelajaran berupa RPP Daring 1 lembar yang memang disiapkan untuk pembelajaran jarak jauh, serta (5) aktivitas pembelajaran di MA Kholafiyah Hasaniyah tidak bersifat vokasional serta tidak diasramakan. Sebagai situasi sosial, MA Kholafiyah Hasaniyah memenuhi syarat karena memiliki unsur tempat (place), pelaku (actor) yang melaksanakan, serta kegiatan (acivity) yang unik dan menarik untuk dikaji lebih jauh.

Untuk mendapatkan hasil riset yang spesifik dan terukur, maka fokus penelitian di MA Kholafiyah Hasaniyah ini diarahkan hanya pada Mapel Akidah kelas X, XI, dan XII karena selain peneliti menjadi asisten guru Mapel Akidah ini dan menjadi wali kelas $X$ juga karena faktor teknis penelitian di mana riset tentang pembelajaran jarak jauh ini harus benar-benar didasarkan pada pemahaman yang mendalam terhadap karakteristik siswa yang diteliti sepanjang proses belajar-mengajar. Meski demikian, dalam pelaksanaannya nanti, penelitian ini juga akan menyebutkan proses pembelajaran pada MapelMapel lain di MA Kholafiyah Hasaniyah sebagai ilustrasi memperkuat apa yang akan diargumentasikan.

\section{Metode}

Penelitian ini menggunakan pendekatan kualitatif deskriptif jenis studi kasus tunggal terpancang (embedded case study research) berusaha menggali sebanyak mungkin fakta sesuai dengan fokus penelitian. Menurut Sutopo, tunggal karena permasalahan dan fokus penelitian mengarah kepada satu karakteristik, satu sasaran atau satu obyek tertentu, sementara terpancang karena fokus penelitian sudah ditentukan sebelum peneliti masuk ke lapangan (Sutopo, 2006).

Penelitian ini dilaksanakan di MA Kholafiyah Hasaniyah di JL. R. Sidharta No. 45 RT 05 RW 03 Gading Wetan, Kec. Gading, Kab. Probolinggo, Prov. Jawa Timur, karena beberapa pertimbangan:

1. MA Kholafiyah Hasaniyah termasuk berada di kawasan zona hijau di Kabupaen Probolinggo yang secara prosedural diizinkan untuk melaksanakan pembelajaran luring dan daring;

2. MA Kholafiyah Hasaniyah telah melaksanakan pembelajaran jarak jauh sesuai dengan kerangka kebiijakan yang telah ditetapkan oleh Kemendikbud RI selama masa Pandemi Covid-19;

3. Selama pelaksanaan pembelajaran jarak jauh ini, MA Kholafiyah Hasaniyah telah mengadopsi 3 strategi pembelajaran, yakni pembelajaran luring, daring, dan home visit, sebagaimana yang telah direkomendasikan oleh Diknas Kab. Probolinggo;

4. Lokasi rumah para guru dan para siswa MA Kholafiyah Hasaniyah secara geografis memungkinkan adanya berbagai opsi pembelajaran, seperti daring, luring, maupun home visit;

5. MA Kholafiyah Hasaniyah juga baru menerapkan desain pembelajaran berupa RPP Daring 1 lembar yang memang disiapkan untuk pembelajaran jarak jauh;

6. Aktivitas pembelajaran di MA Kholafiyah Hasaniyah tidak bersifat vokasional serta tidak diasramakan.

Untuk memperoleh data umum yang berkaitan dengan data umum berkaitan dengan profil MA Kholafiyah Hasaniyah, sarana prasarana 
madrasah, kurikulum pembelajaran jarak jauh, tenaga akademik dan administrasi, serta gambaran umum lain, penelitian ini menggunakan teknik observasi langsung dan wawancara dengan Kepala Madrasah, Waka Kurikulum, Waka Kesiswaan MA Kholafiyah Hasaniyah.

Sementara itu, untuk memperoleh data tentang pelaksanaan pembelajaran jarak jauh di MA Kholafiyah Hasaniyah, serta bagaimana detaildetail proses implementasi pembelajaran jarak jauh di di MA Kholafiyah Hasaniyah, peneliti mewawancarai Guru Mapel Akidah Kelas X, XI, XII, dan beberapa guru Mapel lain, seperti guru Mapel Aswaja, guru Mapel Matematika, dan guru Mapel TIK, serta siswa-siswa kelas X, XI, XII, dan kegiatan pembelajaran.

Adapun data tentang faktor pendukung dan faktor penghambat penerapan pembelajaran jarak jauh di MA Kholafiyah Hasaniyah serta cara mengatasinya, studi ini mengobservasi dan mewawancarai pihak-pihak yang berkepentingan dan berhubungan langsung, seperti Kepala Madrasah, Waka Kurikulum, Kepala Laboratorium, guru Mapel Akidah Kelas X, XI, XII, serta guru mapel lain, dan para siswa, serta kegiatan pembelajaran.

Terakhir, data tentang preferensi belajar siswa yang relevan langsung dengan kemandirian belajar siswa MA Kholafiyah Hasaniyah, studi ini melakukan wawancara dengan Guru Mapel Akidah Kelas X, XI, XII, guru mapel-mapel lain, dan para siswa MA Kholafiyah Hasaniyah, karena merekalh yang secara langsung mengetahui dan merasakan proses pengalaman belajar jarak jauh tersebut.

\section{Diskusi dan Pembahasan}

\subsection{Pembelajaran Jarak Jauh selama Pandemi Covid-19}

Hasil penelitian menunjukkan bahwa proses pembelajaran jarak jauh di MA Kholafiyah Hasaniyah dilakukan melalui beberapa tahap, yaitu

1. tutorial tatap muka sebagai pembekalan program pembelajaran jarak jauh yang diberuntukkan bagi siswa baru,

2. kegiatan belajar mandiri yang di dalamnya terdpat kegiatan tutorial online, praktik / praktikum, tutorial kunjung, dan belajar mandiri, serta

3. evaluasi belajar.
Proses pembelajaran lebih komprehensif akan diuraikan lebih lanjut dan skemanya dapat dilihat pada gambar berikut ini:

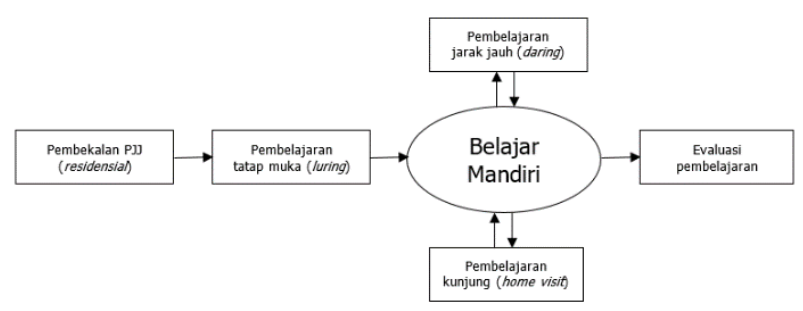

Gambar 2. Proses pembelajaran jarak jauh di MA Kholafiyah Hasaniyah

Berdasarkan pada pelaksanaan pembelajaran jarak jauh MA Kholafiyah Hasaniyah, ditemukan beberapa model pelaksanaan, yakni tutorial tatap muka pada masa residensial, tutorial online, dan tutorial kunjung. Dalam istilah pembelajaran selama masa Pandemi Covid-19 saat ini, ketiga model tutorial ini sering dikenal dengan pembelajaran luring (tutorial tatap muka), pembelajaran daring (tutorial online), dan pembelajaran komunitas / home visit (tutorial kunjung) yang ditujukan untuk memberikan bimbingan khusus dan monitoring hambatanhambatan yang dirasakan selama pembelajaran daring.

Hal ini sejalan dengan pendapat Fathur Rozi, Kepala Dinas Pendidikan Kab. Probolinggo, bahwa selama masa Pandemi Covid-19, ada tiga strategi pembelajaran yang bisa dilakukan oleh sekolah, termasuk oleh MA Kholafiyah Hasaniyah, yakni pembelajaran daring, pembelajaran luring, dan home visit. Menurut Rozi, pembelajaran daring, diterapkan pada sekolah yang memiliki teknologi informasi dan komunikasi memadai juga jaringan internet yang stabil. Hal itu supaya proses pembelajaran yang memanfaatkan gadget tersebut berjalan lancar. Jika kondisinya tak memungkinkan, maka sistem luring dapat dilakukan. Caranya adalah guru hadir ke komunitas tempat tinggal peserta didik (home visit). Jadi guru-guru itu hadir dan mendatangi peserta didik. Tetapi bukan ke rumahnya, namun ke komunitas tempat tinggal. Sementara itu, untuk strategi proses pembelajaran ketiga adalah pembelajaran campuran. Tetapi ini berlaku bagi yang sudah menerapkan daring dengan memadukan pembelajaran luring untuk mengatasi kejenuhan dan kebosanan peserta didik (Tim Jurnalistik, 2020).

Hal ini juga sejalan dengan penelitian yang telah dilakukan oleh Satria Wiguna, dkk., bahwa melaksanakan pembelajaran daring secara full 
pada masa Pandemi Covid-19 ini sulit dilakukan, sebab banyak masalah - masalah lahir dari siswa dalam belajar saat ini misalnya, siswa tidak bisa mengakses internet, masalah quota mahal, siswa tidak punya gadget, siswa tidak aktif bahkan tidak mau peduli untuk belajar, kecenderungan main game on line, begadang malam, siswa tidak pernah atau mau mengirim tugas padahal HP nya selalu online, dan sebagainya (Wiguna \& Al Qadri, 2021). Semua masalah ini harus cepat diantisipasi, diinventarisir, dikomunikasikan serta dicari solusi yang tepat serta bijak oleh sekolah terutama para walikelas dan guru BP/BK, terdokumentasikan berbentuk foto dan video disertai deskripsi catatan dan laporan. Fungsi utama kegiatan home visit ialah fungsi pemahaman, artinya memahami masalah siswa secara detil, mencari solusi masalah yang tepat dan bijak siswa yang barang tentu diperlukan sinergitas sekolah, siswa dan orang tua siswa.

Oleh karena itu, keputusan MA Kholafiyah Hasaniyah untuk melaksanakan home visit di tengah pembelajaran daring dan luring menjadi salah satu alternatif membangun komunikasi yang baik tersebut serta diharapkan bisa membantu memecahkan kesulitan-kesulitan belajar siswa moda daring atau luring saat pandemi ini. Home visit bertujuan untuk memperoleh berbagai keterangan atau data yang diperlukan dalam memahami lingkungan dan siswa serta memecahkan permasalahan siswa yang mengalami kesulitan belajar saat Belajar Dari Rumah. Untuk itu home visit di MA Kholafiyah Hasaniyah menjadi salah satu teknik pengumpulan data siswa yang dilakukan oleh guru BP/BK atau walikelas dengan cara mengunjungi tempat tinggal siswa tertentu yang tujuannya untuk memperoleh informasi yang lebih lengkap dan akurat tentang permasalahan siswa.

Hal ini sejalan dengan penelitian Ahmad bahwa berkunjung ke rumah atau home visit siswa akan diperoleh berbagai data dan keterangan tentang berbagai hal yang besar kemungkinan ada sangkut pautnya dengan permasalahan siswa yakni meliputi : 1) Kondisi dan fasilitas belajar siswa serta masalah kesulitan belajar di rumah, 2) Hubungan siswa dengan orang tua dan anggota keluarganya, 3) Sikap dan kebiasaan siswa di rumah, 4) Komitmen orang tua dan anggota keluarga lainnya dalam perkembangan anak-anaknya dan pengentasan masalahnya (Ahmad, 2020). Dengan home visit ini akan terlahir kedekatan emosional antara wali kelas dan siswa sehingga terciptanya hubungan yang harmonis dan saling timbal balik, pelaksanaan home visit ini bukan hanya tertuju kepada siswa tapi juga kepada keluarga siswa karena dengan dilakukannya home visit ini keluarga juga mendapatkan pandangan, pemahaman, arahan, motivasi, sikap dan cara yang perlu dilaksanakan oleh keluarga siswa.

Kegiatan pembekalan pembelajaran jarak jauh diberikan kepada guru dan siswa MA Kholafiyah Hasaniyah. Materi pembekalan untuk guru adalah kemampuan teknis ICT (internet), sementara materi pembekalan kepada siswa antara lain (a) sistem administrasi MA Kholafiyah Hasaniyah; (b) pengenalan program pembelajaran jarak jauh; (c) media-media belajar pembelajaran jarak jauh; (d) evaluasi pembelajaran jarak jauh; (e) tips dan trik belajar mandiri dari rumah; (f) keterampilan belajar; ( $g$ ) sistem penilaian; (h) keterampilan dasar teknologi informasi.

Ruang lingkup materi pembekalan pembelajaran jarak jauh di MA Kholafiyah Hasaniyah dapat disajikan pada gambar berikut.

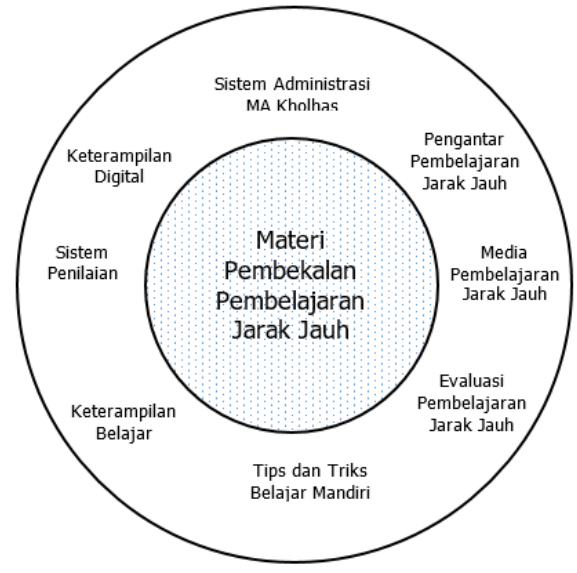

Gambar 3. Ruang lingkup materi pembekalan pembelajaran jarak jauh di MA Kholafiyah Hasaniyah

Hal ini sejalan dengan pendapat Choiriyah dan Riyanto, yang menyebutkan bahwa seorang guru harus memiliki pengalaman dalam pengajaran online, sebab jika sewaktu-waktu terdapat situasi yang mengharuskannya untuk melakukan pengajaran online, pelatihan tentang materi tersebut adalah hal multak yang harus diberikan kepada mereka (Choiriyah \& Riyanto, 2020). Studi lain juga menyebutkan bahwa program pembekalan didesain tidak hanya untuk memberi pembekalan teknis, karena seorang guru harus memiliki kompetensi, antara lain (a) komunikasi interpersonal dan kemampuan memberi umpanbalik, (b) mampu meningkatkan interaksi siswa, (c) memiliki kemampuan administratif dan layanan pendukung, (d) memiliki keterampilan bekerja sama, (e) memiliki pengetahuan untuk melakukan analisis kebutuhan, (f) memiliki pemahaman tentang trend teknologi dan 
dampaknya pada siswa, dan (g) mampu mengembangkan perspektif berpikir yang sistematis (Windarsih, et.al, 2021).

Hal yang sama juga dikatakan oleh Hery Haryanto, dkk., bahwa pandemik global Covid-19 ini telah mengubah cara pembelajaran langsung tatap muka dengan pembelajaran daring, sehingga pembelajaran daring merupakan suatu keniscayaan bagi para guru. Namun kenyataanya sebagian besar guru di sekolah menengah belum menguasai pembelajaran jarak jauh ini. Oleh karena itu, Hery dkk., mencoba memberikan melatih para guru untuk menggunakan aplikasi berbasis Google untuk pembuatan, pengelolaan materi, dan evaluasi pembelajaran jarak jauh di SMAN 8 Kota Bengkulu. Pelatihan dilakukan secara tatap muka langsung dan kegiatan mandiri. Materi pelatihannya adalah penggunaan Google Drive untuk penyimpanan berkas materi, penggunaan Google Classroom untuk pembelajaran jarak jauh, dan penggunaan Google Form untuk evalusi pembelajaran siswa. Hasilnya, Dua puluh empat dari 30 peserta yang dapat menyelesaikan sampai akhir. $60 \%$ peserta menyatakan sangat bermanfaat, 40 persen bermanfaat. Kendala yang dihadapi peserta adalah: waktu yang singkat, kuota internet, sinyal yang tidak selalu lancar, tidak bisa tatap muka, pembelajaran karakter tidak nampak (Haryanto \& Putra, 2020). Kendalakendala ini ternyata juga dihadapi pula oleh para guru dan siswa MA Kholafiyah Hasaniyah, yang mengeluhkan tentang kuota internet, sinyal, kebosanan belajar, hingga rendahnya kemampuan digital mereka.

Hal ini juga sejalan dengan temuan Durratun Nafisah, dkk., bahwa guru perlu dibekali keahlian khusus untuk mendesain pembelajaran jarak jauh. Studi ini memperlihatkan bahwa pelatihan dan pembekalan teknis bisa efektif dalam meningkatkan kemampuan digital guru. Pelatihan mereka dilaksanakan di MAN 1 Surabaya. Seluruh materi disampaikan secara virtual melalui aplikasi Zoom Cloud Meeting mengingat masih dalam masa pandemic covid-19. Peserta yang mengikuti workshop dapat mengakses materi melalui zoom, live facebook dan live streaming youtube. Sebanyak 300 peserta yang mengikuti kegiatan PKM ini diketahui bahwa sebagian besar (73\%) peserta berasal dari sekolah tingkat dasar (SD) dan $14 \%$ berasal dari sekolah menengah pertama (SMP), sisanya berasal dari TK, SMA dan Perguruan Tinggi. Berdasarkan hasil kegiatan bahwa sebagian besar peserta memahami konsep pembelajaran jarak jauh dan mampu mengembangkan desain pembelajaran jarak jauh. Peserta mampu mengembangkan perangkat pembelajaran jarak jauh yaitu RPP dan bahan ajar pembelajaran dalam bentuk luring, daring maupun kombinasi. $100 \%$ peserta mengumpulkan tugas membuat RPP dan bahan ajar melalui google classroom. Sebagian peserta juga mampu dalam mengoperasikan media dan evaluasi pembelajaran digital (Nafisah, et.al, 2020). Hal ini sesuai dengan situasi yang dialami oleh guru dan siswa MA Kholafiyah Hasaniyah, di mana mereka sudah cukup mampu mengoperasikan media digital, seperti Gmail, Google Form, dan Youtube, sebagai salah satu media pembelajaran jarak jauh.

Sebagaimana diketahui, media pembelajaran yang digunakan selama proses pembelajaran jarak jauh di MA Kholafiyah Hasaniyah adalah Whatsapp, Youtube, dan Website untuk komunikasi pembelajaran, sementara untuk evaluasi pembelajaran menggunakan media Google Form. Sekalipun saat ini sudah ada metode e-learning dengan berbagai modul, namun sekolah ini tampaknya belum bisa sampai di level sana, mengingat SDM guru nya masih perlu kemampuan IT yang lebih baik. Untuk menggunakan media-media tersebut, semua guru diwajibkan mengetahui teknis penggunaan E-Mail, karena Youtube dan Google Form tersinkronisasi dengan pesan elektronik.

Hal ini sejalan dengan pendapat Latip bahwa internet menjadi sarana utama yang digunakan oleh siswa dan guru untuk melakukan komunikasi dan interaksi pada proses pembelajaran jarak jauh. Menurut Latip, ada tiga tipe interaksi dalam pembelajaran jarak jauh, yaitu (1) interaksi siswa dan materi, (2) interaksi siswa dan guru, dan (3) interaksi siswa dan siswa (Latip, 2020). Khusus pada pelaksanaan pembelajaran jarak jauh di MA Kholafiyah Hasaniyah, interaksi dilakukan melalui pengiriman materi dan tugas melalui media-media online, seperti Whatsapp, Website, dan Youtube. Tugas-tugas ini dikirimkan oleh siswa melalui internet pada Whatsapp guru masing-masing mata pelajaran, dan masing-masing guru telah membuat Grup Chatting tersendiri sebagai media komunikasi antarmereka. Penggunaan media berbasis internet ini menjadi salah satu ciri dan alasan program pembelajarna jarak jauh ini disebut PJJ berbasis ICT.

Evaluasi pembelajaran dilakukan untuk mengukur keberhasilan siswa dalam mempelajari suatu materi pelajaran, sejauh mana siswa dapat menguasai suatu kompetensi atau kemampuan tertentu yang menjadi tujuan awal mata pelajaran tersebut. Berdasarkan temuan di lapangan, ada beberapa jenis evaluasi hasil belajar yang digunakan di MA Kholafiyah Hasaniyah mengukur 
kemampuan siswa, yaitu tes formatif, tugas mandiri, Penilaian Tengah Semester (PTS), dan Penilaian Akhir Semester (PAS). Selain evaluasi dalam bentuk tes formatif, evaluasi terhadap kualitas pembelajaran dilakukan oleh MA Kholafiyah Hasaniyah melalui kegiatan monitoring di setiap pelaksanaan home visit serta penugasan guru pengamat (observer-teacher) di tiap grup WA kelas.

Hal ini sejalan dengan pedoman yang dikeluarkan oleh Kemendikbud RI tentang pembelajaran jarak jauh selama masa Pandemi Covid-19 bahwa evaluasi dalam pembelajaran jarak jauh dilakukan dengan tetap berprinsip pada beberapa hal sebagai berikut: a) Guru perlu mengelola penilaian sumatif dan memberikan umpan balik dari proses pembelajaran; b) Perlu dipikirkan juga bagaimana guru akan menilai hasil pembelajaran; c) Pada akhirnya, metode penilaian yang digunakan akan tergantung pada tujuan belajar ditetapkan; d) Adanya keseimbangan antara apa yang efektif dan apa yang layak untuk dilakukan dari jarak jauh (Tim Penyusun, 2020).

Hal ini juga dipertegas dengan temuan penelitian Siti Lathifatus S., bahwa salah satu sarana yang digunakan oleh guru untuk mengevaluasi pembelajaran jarak jauh adalah Group Media Sosial dan Google Form. Menurut Lathifatus S., rup media sosial menunjang kebutuhan guru terkait pelatihan pembuatan media pembelajaran daring. Pembelajaran daring sejalan dengan teori pembelajaran konstruktivistik di mana peserta didik menyusun pengetahuan yang digali dari sumber pembelajaran yang disediakan oleh guru. Pemanfaatan teknologi dalam pembelajaran diharapkan lebih meningkatkan pemahaman peserta didik terhadap materi yang dipelajarinya. Pembelajaran daring pada tingkat pendidikan dasar dan menengah pada umumnya menggunakan media evaluasi pembelajaran online. Media evaluasi pembelajaran online termasuk dalam kategori independent media. Studi ini juga menegaskan bahwa Google Forms merupakan media evaluasi pembelajaran online yang paling familiar di kalangan guru (Sun'iyah, 2020). Hasil studi ini relevan dengan fenomena yang terjadi di MA Kholafiyah Hasaniyah, di mana model evaluasi yang dilakukan antara lain melalui Group WA dan Google Form.

Hal ini juga sejalan dengan temuan Ahmad bahwa pada dasarnya prinsip tes daring adalah sama sebagaimana tes konvensional pada umumnya, hanya saja yang menjadi perbedaan adalah media yang digunakan. Bentuk tes dapat dibagi menjadi dua: pertama, Tes Subjektif. Tes yang pada umunya berbentuk esai (uraian). Kedua, Tes Objektif. Tes yang dalam pemeriksaannya dapat dilakukan secara objektif. Tes objektif dibedakan menjadi empat macam, yaitu: (a) Bentuk tes Benar-Salah. Bentuk tes benar-salah memiliki soal yang berupa statement; (b) Bentuk pilihan ganda (multiple choice test); (c) Menjodohkan (matching). Menjodohkan terdiri atas satu sisi pertanyaan dan satu sisi jawaban, setiap pertanyaan mempunyai jawaban pada sisi sebelahnya; dan (d) Tes Isian. Tes isian terdiri dari kalimat yang dihilangkan (diberi titik-titik) (Ahmad, 2020). Temuan ini juga sejalan dengan pelaksanaan evaluasi pembelajaran jarak jauh di MA Kholafiyah Hasaniyah, di mana sebagian besar guru lebih memilih menggunakan tes pilihan ganda, sebagian kecil dengan tes esai, namun semuanya menggunakan Google Form sebagai medianya.

Adapun rangkaian kegiatan pada tiga jenis pembelajaran itu di MA Kholafiyah Hasaniyah dapat dilihat pada Gambar 4 berikut ini.

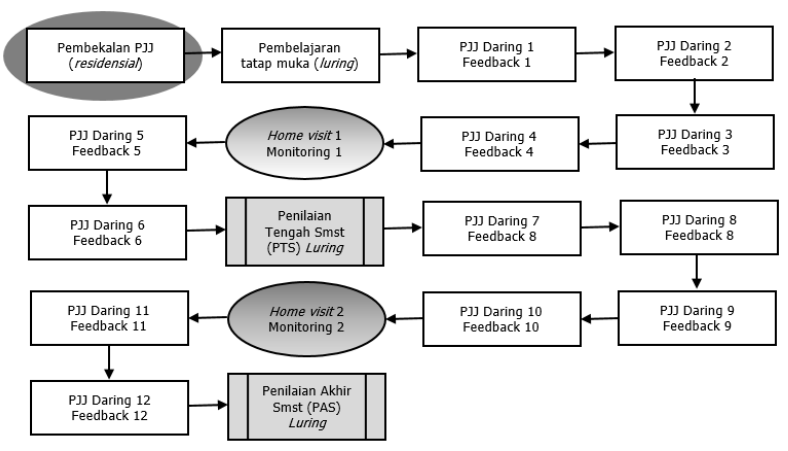

Gambar 4. Rangkaian kegiatan pembelajaran jarak jauh (luring, daring, dan home visit) di MA Kholafiyah Hasaniyah

Rangkaian kegiatan pembelajaran sebagaimana dalam Gambar 4 di atas diselenggarakan selama 1 semester yang dimulai dari pembelajaran luring (masa residensial), pembelajaran daring yang diselenggarkan sesuai dengan jumlah jam mata pelajaran, serta pembelajaran komunitas yang dilaksanakan sebanyak 2 kali di sela-sela pembelajaran jarak jauh.

\subsection{Beberapa Faktor Penghambat dan Kemungkinan Pemecahannya}

Beberapa faktor penghambat pelaksanaan pembelajaran jarak jauh di MA Kholafiyah Hasaniyah serta upaya yang dilakukan oleh 
sekolah tersebut untuk mengatasinya dapat diklasifikasikan sebagai berikut.

Pertama, rendahnya budaya digital siswa dan guru MA Kholafiyah Hasaniyah. Hal ini dapat dilihat dari latar belakang siswa yang rata-rata berasal dari keluarga ekonomi kelas menengah ke bawah dan bertempat tinggal di kawasan yang sulit sinyal, sehingga mereka jarang sekali bersentuhan dengan perangkat elektronik. Upaya untuk mengatasi budaya digital siswa yang masih rendah ini dilakukan oleh pengelola MA Kholafiyah Hasaniyah adalah dengan memprogramkan kegiatan pelatihan peningkatan kemampuan penggunaan media teknologi komunikasi serta 'memaksa' siswa untuk terbiasa bersentuhan dengan internet sejauh itu berkaitan dengan penugasan, pengumuman, dan bahan ajar yang dikirimkan oleh guru mereka masing-masing. Kemampuan digital sebagian guru MA Kholafiyah Hasaniyah juga masih rendah. Hal ini ditunjukkan dengan respons guru terhadap tugas siswa yang dikirimkan lamban, perasaan berat bekerja lewat internet, dan rata-rata mereka memiliki peran ganda saat bekerja dari rumah. Upaya yang dilakukan oleh pihak MA Kholafiyah Hasaniyah untuk meningkatkan budaya digital ini, selain memberikan pelatihan tentang penggunaan media pembelajaran di awal semester, juga dengan melaksanakan joint-teaching di mana guru lain ditugaskan sebagai observer dan asisten bagi guru mapel.

Hal ini sejalan dengan pedoman yang dikeluarkan oleh Kemendikbud RI tentang pembelajaran jarak jauh selama masa Pandemi Covid-19 bahwa dalam pembelajaran jarak jauh, siswa juga perlu menerima umpan balik. Untuk memberikan umpan balik tersebut, ada beberapa fase yang harus diperhatikan oleh guru: a) fase sebelum pembelajaran: mengklarifikasi tugas dan mengelola hasil yang akan diharapkan; b) fase selama pembelajaran: memantau kemajuan dan pembelajaran melalui refleksi secara berkala dan memberikan umpan balik dan dukungan secara terus menerus; c) mengelola penilaian sumatif dan memberikan umpan balik dari proses pembelajaran (Ahmad, 2020). Hal ini juga sejalan dengan pendapat Sutrisno yang menyebutkan bahwa pembelajaran jarak jauh bisa efektif jika dilaksanakan melalui supervisi klinis dengan pendekatan kolaboratif antar-guru (Sutrisno, 2021).

Kedua, kurangnya akses internet. Tidak semua wilayah di Wangkal Gading memiliki akses internet, daerah perkotaan lebih mudah mengakses internet, tetapi di pedesaan, apalagi di dataran tinggi seperti Wangkal, akses internet mengalami kendala. Dampak paling terasa dari akses internet yang kurang baik adalah pengiriman tugas mandiri yang kurang lancar. Akses internet juga sangat menentukan keberhasilan dalam pembelajaran jarak jauh, sebagian siswa atau guru berupaya mengatasi hambatan akses internet dengan pergi ke tempat temannya yang memiliki sinyal bagus atau sebagian lagi memasang jaringan internet pribadi di rumahnya.

Hal ini sejalan dengan pedoman yang dikeluarkan oleh Kemendikbud RI tentang pembelajaran jarak jauh selama masa Pandemi Covid-19 bahwa salah satu desain pembelajaran jarak jauh yang harus dipenuhi adalah sumber daya belajar. Sumber daya yang dibutuhkan untuk meningkatkan pembelajaran tersebut antara lain: a) Memastikan teknologi, platform, peralatan dan sumber daya yang tersedia bagi guru dan siswacetak, audio dan radio, video dan TV, berbasis komputer, berbasis Internet dan berbasis telepon: Manakah dari sumberdaya ini yang dapat digunakan oleh semua atau sebagian besar siswa dan manakah yang termudah untuk digunakan untuk komunikasi, instruksi langsung, diskusi, berbagi pekerjaan dan penilaian? Manakah dari siswa yang tidak memiliki akses ke telepon, komputer, internet?; b) Memastikan materi pengajaran dan pembelajaran yang dapat diadaptasikan untuk pembelajaran jarak jauh. Mencari sumber daya pendidikan yang dapat bebas diakses dan memastikan sumberdayatersebut berkualitas (Tim Penyusun, 2020).

Ketiga, rendahnya motivasi belajar dan berprestasi siswa. Motivasi belajar dan berprestasi siswa di sini adalah keinginan siswa untuk belajar dan berprestasi selama pembelajaran jarak jauh di MA Kholafiyah Hasaniyah. Rendahnya motivasi belajar dan berprestasi ini menjadi penghambat pelaksanaan pembelajaran jarak jauh di MA Kholafiyah Hasaniyah. Indikator rendahnya motivasi belajar ini bisa dilihat dari gejala motivasi belajar dan berprestasi ini bisa dilihat dari banyaknya kasus copy paste jawaban tugas mandiri, membaca seadanya saja, ungkapan yang penting lulus, yang penting mengumpulkan tugas, dan sejenisnya. Upaya untuk mengatasi hambatan motivasi belajar dan berpretasi siswa yang rendah ini, ditinjau dari sudut pengelola MA Kholafiyah Hasaniyah, antara lain: pembekalan program pembelajaran jarak jauh, motivasi belajar, 
pemantauan secara berkala di Grup WA, hingga monitoring saat home visit.

Hal ini sejalan dengan pedoman yang dikeluarkan oleh Kemendikbud RI tentang pembelajaran jarak jauh selama masa Pandemi Covid-19 bahwa guru perlu memberikan dukungan kepada siswa selama proses pembelajaran jarak jauh. Dukungan tersebut bisa berupa dukungan mental maupun emosional untuk menjaga siswa tetap terlibat dan termotivasi untuk belajar, serta membantu mereka mengatasi kecemasan dan ketakutan mengadapi pembelajaran (Tim Penyusun, 2020). Hal ini juga sejalan dengan pendapat Hapsari, dkk., bahwa peran guru sangat menentukan keberhasilan belajar dan stabilitas emosi siswa selama menjalani pembelajaran jarak jauh pada masa Covid-19 (Hapsari, et.al, 2021).

Keempat, minimnya dukungan sarana belajar. Keterbatasan sarana belajar, seperti laptop dan $\mathrm{hp}$, menjadi kendala utama dalam pelaksanaan pembelajaran jarak jauh di MA Kholafiyah Hasaniyah. Dari hasil penelitian ditemukan bahwa banyak siswa yang tidak memiliki laptop dan hp, disebabkan oleh faktor-faktor eksternal seperti perizinan orang tua atau pun faktor internal seperti ketidakmampuan mengoperasikan, sehingga mereka mengalami kesulitan mengikuti pembelajaran. Salah satu cara untuk mengatasi permasalah tersebut adalah memberikan dorongan kepada orang tua untuk membantu anaknya mengakses $\mathrm{Hp}$ dan tentu saja mengawasinya, serta mengupayakan memberikan fasilitas kredit laptop dan $\mathrm{Hp}$.

Hal ini sejalan dengan pendapat Rifanisari dan Badarudin bahwa media pembelajaran dipandang sebagai suatu pilihan bahkan keharusan dalam strategi pembelajaran jarak jauh, sekalipun sarana atau media tersebut hanya berupa Whatsapp (Rifanisari \& Badrudin, 2021). Hal ini mengisyaratkan bahwa dalam memilih strategi pembelajaran memilih kondisi pembelajaran aspek media sangat penting untuk dipertimbangkan. Pemilihan dan penggunaan media pembelajaran merupakan bagian dari penerapan strategi pembelajaran. Pendidik harus memiliki kemampuan, wawasan, ketrampilan dan profesionalisme dalam memilih dan mengunakan media untuk pembelajaran. Sri Anitah menyebutkan bahwa berbagai sistem telekomunikasi yang dapat digunakan sebagai media dalam PJJ diantaranya siaran radio, teleconfrensi audio, telivisi, android, beserta dengan semua aplikasi di dalamnya (Wahid, et.al, 2020).

Semua kendala yang dihadapi oleh siswa dan guru MA Kholafiyah Hasaniyah ini juga relevan dengan temuan Muhammad Fikri, dkk., bahwa pembelajaran jarak jauh atau bisa disebut juga pembelajaran daring merupakan pembelajaran yang menggunakan jaringan internet dengan aksesibilitas, konektivitas, fleksibilitas, dan kemampuan untuk memunculkan berbagai jenis interaksi pembelajaran, ini merupakan solusi pembelajaran ditengah pandemi. Tetapi, dalam pembelajaran jarak jauh masih ada permasalahan yang menjadi hambatan atau kendala dalam pelaksanaannya. Untuk mengetahui itu semua Metode yang digunakan adalah pendekatan deskriptif kualitatif dengan jenis penelitian kepustakaan yaitu mengumpulkan data yang tertumpu pada penelaahan kritis dan mendalam terhadap bahan-bahan pustaka yang relevan dan di dapat bahwa kendala yang dihadapi peserta didik dan pengajar dalam proses pembelajaran daring selama pandemic ini masih pada kategori sangat mendasar atau fundamental. Kendala yang sering dihadapi seperti terbatasnya layanan pembelajaran yang diberikan, Kurangnya pemahaman penggunaan aplikasi pembelajaran, dan kendala internet (Fikri, et.al, 2021). Semua kendala ini harus menjadi salah satu hal yang harus diperhatikan baik pemerintah, instansi kependidikan, pengajar dan peserta didik saat mempersiapkan dan melaksanakan pembelajaran online, tak terkecuali juga di MA Kholafiyah Hasaniyah.

\subsection{Dampak Pembelajaran Jauh bagi Kemandirian Belajar Siswa}

Hasil penelitian memperlihatkan bahwa pembelajaran jarak jauh tidak memberi dampak signifikan terhadap kemandirian siswa di MA Kholafiyah Hasaniyah. Hal ini, disebabkan, secara konseptual karena ada beberapa prasyarat efektivitas pembelajaran jarak jauh yang tidak dipenuhi oleh sekolah ini. Menurut Rodame Monitorir Napitupulu (2020), banyak faktor yang memengaruhi kepuasan pembelajaran jarak jauh di antaranya: teknologi, konten edukasi, motivasi dan sikap, tingkat kesiapan mahasiswa, kesesuaian informasi dengan kebutuhanm desain pembelajaran, kualitas informasi, pengalaman (Napitulu, 2020). Beberapa hal tersebut menjadi penting untuk diperhatikan guna melaksanakan pembelajaran jarak jauh yang lebih menarik, memudahkan siswa dalam menerima materi serta menyenangkan. 
Di MA Kholafiyah, beberapa prasyarat tersebut tidak bisa terpenuhi dengan baik. Banyak siswa dan guru masih gagap teknologi. Masalah teknis sinyal dan internal akibat letak geografis juga menjadi salah satu kendala. Konten edukasi berupa modul atau materi pelajaran, diakui oleh beberapa siswa dan guru, juga masih tetap seperti tahun-tahun sebelumnya. Motivasi dan sikap tanggung jawab belajar siswa dan guru juga rendah, misalnya terlambat atau tidak memberikan balikan sama sekali dan indikasi maraknya copy paste teugas mandiri. Kualitas informasi tentang pembelajaran jarak jauh tidak maksimal karena pembekalan dilaksanakan kurang efektif disebabkan kondisi ruangan dan jumlah siswa yang terlibat di dalamnya. Ditambah lagi pengalaman mereka menggunakan teknologi dan perangkat internet tidak merata.

Salah satu aspek yang mempengaruhi proses pembelajaran jarak jauh yaitu aspek kesiapan peserta didik dalam menerima dan mengikuti pembelajaran jarak jauh. Kesiapan tidak hanya pada unsur fisik berupa kepemilikan media pembelajaran daring (smartphone, laptop, dII) dan kemampuan mengoperasikan aplikasi, melainkan juga kesiapan psikologis dalam menjalani proses pembelajaran jarak jauh. Kedua unsur tersebut harus diperhatikan dalam menerapkan pembelajaran jarak jauh, karena dapat berpotensi untuk menghambat tercapainya tujuan pembelajaran serta berdampak kepada hasil belajar peserta didik. Situasi yang terjadi di MA Kholafiyah Hasaniyah adalah banyak guru dan siswa tidak memiliki perangkat elektronik dan terkendala sinyal akibat letak geografis. Tidak semua dari mereka juga mampu mengoperasikan aplikasi elektronik, seperti Gmail, Google Form, dan Youtube.

Kesiapan peserta didik secara psikologis, terlihat melalui keaktifan dalam mengikuti proses pembelajaran jarak jauh, dengan segala bentuk konsekuensinya. Minimya durasi waktu tatap muka dengan guru mapel, minimnya waktu beriteraksi dengan siswa lain, tingkat kesulitan materi pelajaran yang sama dengan pembelajaran tatap muka, banyaknya penugasan mandiri atau berkelompok, siswa dituntut untuk menambah durasi belajar mandiri di rumah guna memahami dan memenuhi penugasan dan sebagainya. Hal tersebut data memicu kejenuhan siswa dalam pembelajaran jarak jauh, terlihat melalui tingkat keikutsertaaan siswa dalam setiap kali pertemuan tatap muka melalui platform daring (zoomeet, googlemeet, dan lain-lain). Perilaku tersebut menunjukan bahwa kesiapan secara psikologis salah satunya yaitu kemandirian belajar. Sayangnya, di MA Kholafiyah Hasaniya, platform live-presentation seperti Zoom Meeting di atas tidak digunakan, sehingga untuk mengetahui tingkat keikutsertaan siswa dalam pembelajaran jarak jauh, mereka mendelegasikan guru lain terlibat dalam Group WA Kelas atau ikut serta dalam pelaksanaan home visit sebagai bentuk evaluasi pembelajaran.

Dalam sistem pembelajaran jarak jauh, proses pembelajaran sangat menekankan kepada kemandirian belajar peserta didik. Rozi dan Lana, mengungkapkan yang dimaksud dengan belajar mandiri adalah kegiatan belajar aktif, yang didorong oleh niat atau motif untuk menguasai suatu kompetensi guna mengatasi suatu masalah, dan dibangun dengan bekal pengetahuan atau kompetensi yang telah dimiliki (Rozi \& Lana, 2021). Nindiati menjelaskan bahwa belajar mandiri adalah cara belajar yang memberikan derajat kebebasan, tanggung jawab dan kewenangan yang lebih besar kepada pembelajar dalam merencanakan dan melaksanakan kegiatan-kegiatan belajarnya (Nindiati, 2020).

Sebagaimana yang diungkapkan oleh Makur, dkk., salah satu prinsip kesuksesan belajar dalam program pembelajaran jarak jauh adalah kemandirian siswa untuk belajar (indipendent learning) (Makur, et.al, 2021). Dalam belajar mandiri, inisiatif merupakan indikator yang sangat mendasar. Dalam pengertian yang lebih luas, kemandirian belajar mendeskripsikan sebuah proses di mana individu mengambil inisiatif sendiri dengan atau tanpa bantuan orang lain, untuk mendiagnosis kebutuhan belajar, menformulasikan tujuan belajar, mengidentifikasi sumber belajar, memilih dan menentukan pendekatan strategi belajar, dan melakukan evaluasi hasil belajar yang ingin dicapai.

Irzan Tahar merumuskan sintesis kemandirian belajar dalam tiga dimensi, yaitu pengelolaan belajar, tanggung jawab belajar, dan pemanfaatan sumber belajar (Tahar \& Enceng, 2006). Berdasarkan hasil temuan di lapangan, tiga dimensi kemandirian belajar di MA Kholafiyah Hasaniyah dapat disimpulkan sebagai berikut.

Pertama, dimensi pengelolaan belajar. Dimensi pengelolaan belajar berarti siswa mampu mengatur strategi, waktu, dan tempat untuk melakukan aktivitas belajarnya. Indikasi pengelolaan belajar adalah siswa mengalami perubahan dalam kebiasaan belajar, yaitu dengan cara mengatur dan mengorganisasi tujuan, 
kebutuhan, dan strategi belajar yang mengarah pada pencapaian tujuan belajar yang telah dirumuskan. Pada pelaksanaan pembelajaran jarak jauh di MA Kholafiyah Hasaniyah ditemukan adanya perubahan perilaku siswa, yaitu peningkatan intensitas belajar dan akses internet sebagai sumber dan media belajar, namun perubahan perilaku ini terkesan 'formalistik' untuk penyelesaian tugas mandiri semata, bukan kebutuhan untuk menambah wawasan dan pengetahuan atau mencari referensi belajar dalam upaya mencapai tujuan belajar.

Lemahnya dimensi pengelolaan belajar siswa selama pembelajaran jarak jauh di MA Kholafiyah Hasaniyah ini memang menjadi salah satu kendala utama yang juga ditemukan dalam riset-riset lain, seperti temuan Dina Sri Nindati, yang menyebutkan bahwa pelaksanaan pembelajaran jarak jauh harus dikelola dengan sistematis dimulai dari penyusunan silabus materi, pemilihan aktivitas belajar, dan strategi pembelajarannya, merumuskan struktur materi dan memilih aktivitas yang relevan, adapun tugas yang diberikan harus mempertimbangkan beban, waktu, dan kemampuan siswa. Untuk mengatasi hal tersebut, sekolah perlu memberikan minimal 3 jenis layanan, yakni layanan komunikasi (seperti SMS, Whatsapp, Facebook), layanan pengawasan (seperti chatting, video call, maupun home visit), dan layanan pendampingan (seperti pembekalan kepada siswa dan guru) (Nindiati, 2020). Ketiga layanan ini sebenarnya sudah dilakukan juga oleh MA Kholafiyah Hasaniyah, namun tidak semua SDM guru dan siswa berada di level kemampuan yang sama, sehingga sekolah ini memang kesulitan untuk menjaga kemandirian siswa dalam mengelola belajarnya sendiri.

Kedua, dimensi tanggung jawab belajar. Dimensi tanggung jawab berarti siswa mampu menilai aktivitas, mengatasi kesulitan, dan mengukur kemampuan yang diperoleh dari belajar mandiri. Temuan penelitian pada pembelajaran jarak jauh di MA Kholafiyah Hasaniyah terindikasi jawaban tugas mandiri siswa sama (copy paste). Indikasi jawaban tugas copy paste menunjukkan masih rendahnya tanggung jawab siswa dalam belajar mandiri.

Fenomena rendahnya tanggung jawab belajar ini selama masa Pandemi Covid-19 ini juga ditemukan pula dalam penelitian lain, misalnya, oleh M. Sobri, dkk., yang menyebutkan bahwa $50 \%$ siswa mengaku jarang menetapkan tujuan dan strategi belajar jarang mengevaluasi strategi, jarang membuat jadwal belajar dan menepatinya, jarang mempelajari terlebih dahulu materi yang akan dikuliahkan, jarang mempelajari dan mengulang kembali materi, jarang mengerjakan soal-soal latihan yang bukan tugas sekolah, dan jarang memanfaatkan waktu luang untuk mempelajari materi perkuliahan. Dengan demikian, masih banyak siswa yang belum memiliki kemandirian belajar. Hal tersebut dimungkinkan karena mereka kurang terbiasa dan perlu ditingkatkan lagi kemandirian belajarnya (Sobri, et.al, 2020). Salah satu cara yang bisa ditempuh untuk menyelesaikan masalah ini adalah mengajarkan siswa dengan self-management, utamanya manajemen waktu, menyusun jadwal sendiri, membuat prioritas, meminimalisir gangguan, dan lain-lain (Sobri, et.al, 2020). Strategi ini sebenarnya sudah diterapkan oleh MA Kholafiyah Hasaniyah pada saat pembekalan kepada siswa dan guru, di mana salah satu materi yang disampaikan adalah tentang tips-tips belajar mandiri, yang di dalamnya menjelaskan soal manajemen waktu. Akan tetapi, kendala tanggung jawab ini merupakan efek dari sikap individu siswa sendiri yang umumnya belum didukung oleh motivasi dari orang tua mereka masing-masing, sehingga untuk menumbuhkan rasa tanggung jawab dengan hanya bergantung pada sekolah juga sangat sulit dilakukan.

Ketiga, dimensi pemanfaatan sumber belajar. Dimensi pemanfaatan berbagai sumber belajar berarti siswa dapat menggunakan berbagai sumber belajar, seperti modul, internet, aplikasi elektronik, dan lain sebagainya. Pada pelaksanaan pembelajaran jarak jauh di MA Kholafiyah Hasaniyah, pemanfaatan berbagai sumber belajar sangatlah terbatas, kurang beragam dan bervariasi. Hal ini ditunjukkan dengan temuan penelitian bahwa siswa hanya menggunakan modul dan buku ajar sebagai sumber belajar utama dan internet sebagai sumber belajar tambahan. Termasuk dalam pemanfaatan sumber belajar adalah interaksi siswa dengan guru sebagai referensi dan sumber untuk belajar, di MA Kholafiyah Hasaniyah interaksi guru dan siswa juga masih rendah.

Persoalan pemanfaatan sumber belajar oleh siswa MA Kholafiyah Hasaniyah ini sebenarnya juga sejalan dengan temuan penelitian lain, yang menyebutkan bahwa selama siswa tidak mampu memanfaatkan sumber belajar yang ada untuk meningkatkan kemandirian belajarnya, maka selama itu pula mereka tidak akan mampu maksimal mengikuti pembelajaran jarak jauh. Padahal, sumber belajar sangatlah banyak, 
meliputi semua unsur (data, orang, dan barang), yang dapat digunakan oleh peserta didik baik secara terpisah maupun dalam bentuk gabungan, biasanya dalam situasi informal, untuk memberikan fasilitas belajar. Sumber-sumber yang digunakan dan diciptakan dalam teknologi pendidikan sering disebut alat, bahan, perlengkapan, latar, dan orang. Sumber-sumber itu juga bisa berupa materi-materi belajar termasuk video, buku, kaset audio, pelatihan berbasis komputer, program video interaktif, bersama-sama dengan paket belajar yang mengombinasikan media tersebut (Sudatha, et.al, 2020).

Ketiga dimensi belajar mandiri di atas sesuai dengan hakikat pembelajaran jarak jauh, yakni kemandirian belajar (independent learning). Dalam pembelajaran jarak jauh, peserta didik dituntut untuk menjadi pembelajar mandiri (Tahar \& Enceng, 2006). Akan tetapi, dalam kenyataannya, kadar kemampuan belajar mandiri sangat bervariasi karena dipengaruhi oleh banyak faktor. Makin tinggi kendali peserta didik atas pembelajaran yang sedang dijalaninya, dan dengan sendirinya kesiapannya untuk belajar mandiri juga semakin tinggi (Rozi \& Lana, 2021). Keterampilan belajar (learning skills), yang merupakan modal utama dalam belajar mandiri, sikap dan persepsi peserta didik terhadap belajar yang terkait dengan pendekatan belajar, serta berbagai kondisi eksternal lain juga ikut mempengaruhi kesiapan peserta didik untuk belajar mandiri (Makur, et.al, 2021).

Terlepas dari itu semua, harus diakui, bahwa tiga dimensi belajar mandiri di atas tetap belum bisa dipecahkan secara maksimal disebabkan karena kurangnya kerjasama dan interaksi antara guru dan orang tua siswa untuk mengendalikan emosi siswa selama pembelajaran daring. Hasil studi menjelaskan bahwa pola interaksi guru dan orangtua dalam mengendalikan emosional siswa sulit terjalin dengan baik karena adanya salah satu peraturan yang mengharuskan social distancing pada saat pandemi seperti ini. Hal ini mengakibatkan emosi siswa lebih sulit terkontrol karena kurangnya komunikasi antarguru dan orang tua untuk membahas strategi apa yang diharus diterapkan dalam mengendalikan emosional siswa (Limbong, et.al, 2020). Tidak stabilnya emosi siswa selama belajar mandiri di rumah jelas akan berdampak pada kurang maksimalnya mereka memanfaatkan segala sumber belajar, termasuk berinteraksi dengan guru-guru mereka, untuk belajar di rumah.
Pada masa pandemic Covid 19, waktu belajar siswa MA Kholafiyah Hasaniyah sebenarya cukup banyak dan panjang. Namun hal ini bagi sebagian besar siswa memanfaatkan waktu belajar yang panjang dengan melakukan aktivitas yang tidak mendukung proses pembelajaran. Hal ini disebabkan salah satunya, menurut peneliti, karena kontrol orang tua dan kesadaran siswa akan pentingya belajar bagi perkembangan potensi yang dimilikinya. Fenomena semakin ramainya warnet di saat jam belajar siswa, seringnya siswa melakukan aktivitas nongkrong di malam hari, adanya siswa yang kecanduan dalam bermain game online melalui media smartphone. Peristiwa tersebut merupakan indikator bahwa tingkat kesadaran siswa akan belajar mandiri masih kurang, sehingga siswa masih belum mampu mengelola waktu belajar dengan baik.

Kurangnya kesadaran belajar di kalangan siswa MA Kholafiyah Hasaniyah ini muncul seiring dengan bertambahnya perilaku menyimpang yang dilakukan oleh siswa. Perilaku yang tidak mendukung proses pembelajaran seara daring sering dilakukan oleh siswa misalnya, dengan sengaja tidak mengerjakan tugas, tidak mengikuti pembelajaran daring dengan rasionalisasi hambatan koneksi internet dan pemutusan sumber daya lisrik di lokasi rumah, dan sebagainya. Maka dalam menumbuhkan kesadaran siswa untuk belajar secara mandiri diperlukan kolaborasi antara guru, pihak sekolah, siswa, dengan orang tua.

Bagaimanapun, peran orang tua orang tua memiliki peran cukup besar terhap keberhasilan pengembangan nailai-nilai karakter di rumah. Pada masa pandemi covid-19 ini intensitas komunikasi orangtua dan anak sangat tinggi. Dalam pngembangan nilai-nilai karakter di rumah, orang tua berperan sebagai fasilitator yang membantu anak untuk pengembangan karakter secara efektif. Orang tua juga harus mampu bertindak sebagai filterasi yang membantu anak menyaring berbagai pengaruh negatif yang berdampak tidak baik bagi perkembangannya. Orang tua juga mampu berperan sebagai penghubung anak dengan berbagai sumbersumber belajar yang dekat dengan lingkungannya sehari-hari, dan orang tua juga berperan sebagai katalisator, agar mampu menggali dan mengoptimalkan potensi yang dimiliki oleh anak.

Akan tetapi, menurut Maulana, peran orang tua dalam mengontrol perilaku anak remaja belum nampak jelas. Hal ini dibuktikan bahwa orang tua 
justru memberikan kebebasan kepada anak untuk melakukan apa yang diinginkan anaknya tanpa melihat dampak yang ditimbulkan. Misalnya, anak diberikan fasilitas kendaraan bermotor oleh orang tua, tanpa disertai dengan kontrol terhadap pergaulan, sikap dan peningkatan prestasi akademiknya. Hal ini memicu terjadinya penyalahgunaan fasilitas yang dilakukan oleh remaja untuk kegiatan yang kurang adaptif misal, geng motor, berkendara secara ugal-ugalan, balap liar, dan lain sebagainya (Maulana, 2019).

Di MA Kholafiyah Hasaniyah ini, peran orang tua memang kurang maksimal dilibatkan, padahal merekalah yang hampir 24 jam bersama anakanaknya di rumah, dan mereka pula yang sebenarnya paling menentukan keberhasilan belajar mandiri siswa MA Kholafiyah Hasaniyah. Selama orang tua tidak mampu membantu guru untuk mengawasi belajar anak selama Pandemi Covid-19 ini, maka sebagus apapun sistem manajemen yang diterapkan oleh sekolah tidak akan berdampak signifikan terhadap perubahan perilaku belajar mandiri siswa.

Selain peran orang tua, kegiatan belajar bisa berlangsung dengan baik dan memberikan perkembangan bagi potensi siswa bila didukung dengan penyediaan fasilitas belajar yang cukup memadai. Penyediaan sarana dan prasarana pembelajaran daring juga perlu dimiliki dan disiapkan, khususnya adalah sarana media pembelajaran daring yang berbasis internet. Di MA Kholafiyah Hasaniyah, sarana pembelajaran daring belum menggunakan media e-learning, tetapi menggunakan platform-platform lain, seperti Whatsapp, Youtube, dan Google Form. Hal ini memang diakui sedikit menyulitkan guru dan pengelola MA Kholafiyah Hasaniyah dalam melakukan monitorng dan pengawasan kepada pembelajaran jarak jauh.

Ketrampilan guru dalam menyampaikan dan memberikan materi melalui platform daring juga sangat mendukung minat siswa dalam mengikuti pembelajaran. Akan tetapi, di MA Kholafiyah Hasaniyah, masih sedikit guru yang terampil dan kreatif memberikan materi pelajaran, karena terkendala media pembelajaran dan waktu yang mereka miliki untuk melayani pembelajaran siswa. Meski demikian, ada guru MA Kholafiyah Hasaniyah, misalnya guru mapel PJOK, yang cukup kreatif menyajikan materi pembelajaran dan simulasi olahraga di Youtube, sehingga memudahkan siswa untuk memahami materi yang ia sampaikan. Bentuk penugasan ini sengaja disesuaikan dengan materi serta kondisi lingkungan serta perkembangan siswa akan mampu menumbuhka dorongan bagi siswa agar tetap disiplin dalam memenuhi setiap penugasan. Hal tersebut mendorong siswa untuk belajar secara mandiri dan mengeksplorasi wawasan melalui aktivitas belajar berbasis daring.

Dengan demikian, dari analisis terhadap hasil penelitian yang dilakukan di MA Kholafiyah Hasaniyah ini dapat disimpulkan bahwa siswa yang memiliki kemandirian belajar yang baik mampu untuk mengikuti pembelajaran secara daring dengan optimal. Bahkan waktu belajar yang panjang dan koneksi jaringan yang memadai digunakan sebagai kesempatan untuk mengekplorasi pengetahuan dan pemahaman tentang materi pelajaran. Apalagi didukung dengan peran orang tua yang membantu memotivasi anak untuk tetap belajar mesikpun dalam kondisi virtual atau bukan tatap muka. Sebaliknya bagi siswa yang belum memiliki kemandirian dalam belajar, kesempatan untuk belajar secara mandiri dalam pembelajaran daring belum digunakan dengan baik. Banyak aktivitas yang kurang mendukung pembelajaran yang dilakukan siswa, sehingga menghambat perkembangan potensi akademik siswa.

\section{Penutup}

Berdasarkan hasil temuan penelitian, maka dapat diambil beberapa kesimpulan sebagai berikut: Pertama, pembelajaran jarak jauh di MA Kholafiyah Hasaniyah selama masa Pandemi Covid-19 saat ini dilakukan melalui beberapa model pelaksanaan, yakni pembelajaran luring (tutorial tatap muka), pembelajaran daring (tutorial online), dan pembelajaran komunitas / home visit (tutorial kunjung) yang ditujukan untuk memberikan bimbingan khusus dan monitoring hambatan-hambatan yang dirasakan selama pembelajaran daring. Media pembelajaran yang digunakan selama proses pembelajaran jarak jauh adalah Whatsapp, Youtube, dan Website untuk komunikasi pembelajaran, sementara untuk evaluasi pembelajaran menggunakan media Google Form.

Kedua, beberapa faktor penghambat pelaksanaan pembelajaran jarak jauh di MA Kholafiyah Hasaniyah serta upaya yang dilakukan oleh sekolah untuk mengatasinya, antara lain: (1) rendahnya budaya digital siswa dan guru MA Kholafiyah Hasaniyah, dan solusinya adalah, selain memberikan pelatihan tentang penggunaan media pembelajaran di awal semester, juga 
dengan melaksanakan joint-teaching di mana guru lain ditugaskan sebagai observer dan asisten bagi guru mapel; (2) kurangnya akses internet, dan solusinya adalah dengan pergi ke tempat temannya yang memiliki sinyal bagus atau sebagian lagi memasang jaringan internet pribadi di rumahnya; (3) rendahnya motivasi belajar dan berprestasi siswa, dan solusinya pembekalan program pembelajaran jarak jauh, motivasi belajar, pemantauan secara berkala di Grup WA, hingga monitoring saat home visit; (4) minimnya dukungan sarana belajar, dan solusinya adalah memberikan dorongan kepada orang tua untuk membantu anaknya mengakses Hp dan tentu saja mengawasinya, serta mengupayakan memberikan fasilitas kredit laptop dan $\mathrm{Hp}$.

Ketiga, terdapat tiga dimensi kemandirian belajar siswa MA Kholafiyah Hasaniyah selama pembelajaran jarak jauh, yakni (1) dimensi pengelolaan belajar, ditemukan adanya perubahan perilaku siswa MA Kholafiyah Hasaniyah, yaitu peningkatan intensitas belajar dan akses internet sebagai sumber dan media belajar, namun perubahan perilaku ini terkesan 'formalistik' untuk penyelesaian tugas mandiri semata, bukan kebutuhan untuk menambah wawasan dan pengetahuan atau mencari referensi belajar dalam upaya mencapai tujuan belajar; (2) dimensi tanggung jawab belajar, ditemukan adanya indikasi jawaban tugas mandiri siswa MA Kholafiyah Hasaniyah yang sama (copy paste); indikasi jawaban tugas copy paste menunjukkan masih rendahnya tanggung jawab siswa dalam belajar mandiri; (3) dimensi pemanfaatan sumber belajar, ditemukan banyak siswa yang hanya menggunakan modul dan buku ajar sebagai sumber belajar utama dan internet sebagai sumber belajar tambahan.

Pelaksanaan pembelajaran jarak jauh di MA Kholafiyah Hasaniyah hanya berdampak minimal pada pembentukan kemandirian belajar siswa. Meski demikian, dari kesimpulan ini, ada implikasi yang patut diapresiasi dari pelaksanaan pembelajaran jarak jauh di sekolah ini, antara lain: kebiasaan siswa untuk menggunakan perangkat elektronik untuk pembelajaran mulai meningkat; kemampuan guru membuat perangkat pembelajaran berbasis daring, seperti RPP Daring, Prota dan Promes, juga mulai terbentuk; dan kreativitas untuk melaksanakan ujian daring dan home visit, juga sudah mulai terasa manfaatnya di MA Kholafiyah Hasaniyah.

\section{Referensi}

Ahmad, A. (2020). Peningkatan Kompetensi Pedagogik Guru dalam Pembelajaran Jarak Jauh Melalui Pendampingan Sistem Daring, Luring, atau Kombinasi pada Masa New Normal Covid-19. Jurnal Paedagogy, 7(4), 258-264.

Ahmad, I. F. (2020). Asesmen Alternatif Dalam Pembelajaran Jarak Jauh Pada Masa Darurat Penyebaran Coronavirus Disease (Covid-19) di Indonesia. Pedagogik: Jurnal Pendidikan, 7(1), 195-222.

Baharun, H., Islam, S., Muali, C., Ghufron, M. I., el Iq Bali, M., Wijaya, M., \& Marzuki, I. (2018, November). To boost students' motivation and achievement through blended learning. In Journal of Physics: Conference Series (Vol. 1114, No. 1, p. 012046). IOP Publishing.

Choiriyah, S., \& Riyanto, S. (2020). Desain Pelatihan pada Masa Pendemi Covid19. Syntax Idea, 2(8), 488-502.

Depdiknas. (2006). Pengantar Pendidikan Jarak Jauh (PJJ): Konsorsium Program PJJ S-1 PGSD. Jakarta: Depdiknas

Fikri, M., Faizah, N., Elian, S. A., Rahmani, R., Ananda, M. Z., \& Suryanda, A. (2021). Kendala Dalam Pembelajaran Jarak Jauh di Masa Pandemi Covid-19: Sebuah Kajian Kritis. Jurnal Education and Development, 9(1), 145-145.

Hapsari, F., Desnaranti, L., \& Wahyuni, S. (2021). Peran Guru dalam Memotivasi Belajar Siswa selama Kegiatan Pembelajaran Jarak Jauh. Research and Development Journal of Education, 7(1), 193-204.

Haryanto, H., \& Putra, A. H. (2020, December). Pelatihan Pembelajaran Daring Berbasis Aplikasi Google di Masa Pandemik Covid-19 di SMAN 8 Kota Bengkulu. In Prosiding Seminar Nasional Pengabdian Kepada Masyarakat (Vol. 1, pp. SNPPM2020P-145).

Kusuma, J. W., \& Hamidah, H. (2020). Perbandingan hasil belajar matematika dengan penggunaan platform Whatsapp Group dan webinar Zoom dalam pembelajaran jarak jauh pada masa pandemik Covid 19. JIPMat, 5(1). 
Latip, A. (2020). Peran Literasi Teknologi Informasi dan Komunikasi pada Pembelajaran Jarak Jauh di Masa Pandemi Covid-19. EduTeach: Jurnal Edukasi dan Teknologi Pembelajaran, 1(2), 108-116.

Limbong, M., Ali, S., Rabbani, R., \& Syafitri, E. (2020). Pola Interaksi Guru dan Orang Tua dalam Mengendalikan Emosional Siswa Selama Pembelajaran Daring di MTs Islamiyah Medan. THORIQOTUNA: Jurnal Pendidikan Islam, 3(1), 44-55.

Makur, A. P., Jehadus, E., Fedi, S., Jelatu, S., Murni, V., \& Raga, P. (2021). Kemandirian Belajar Mahasiswa dalam Pembelajaran Jarak Jauh Selama Masa Pandemi. Mosharafa: Jurnal Pendidikan Matematika, 10(1), 1-12.

Makur, A. P., Jehadus, E., Fedi, S., Jelatu, S., Murni, V., \& Raga, P. (2021). Kemandirian Belajar Mahasiswa dalam Pembelajaran Jarak Jauh Selama Masa Pandemi. Mosharafa: Jurnal Pendidikan Matematika, 10(1), 1-12.

Maulana, M. A. (2019). Studi Kasus Kenakalan Remaja Tingkat Sekolah Menegah Pertama di Kota Sukoharjo. Edudikara: Jurnal Pendidikan Dan Pembelajaran, 4(1), 23-39.

Nafisah, D., Ghofur, A., Eryadini, N., Rachma, E. A., Youhanita, E., \& Sidi, A. (2020). Workshop Virtual Pengembangan Desain Pembelajaran Jarak Jauh. BERNAS: Jurnal Pengabdian Kepada Masyarakat, 1(4), 454464.

Napitupulu, R. M. (2020). Dampak Pandemi Covid-19 terhadap Kepuasan Pembelajaran Jarak Jauh. Jurnal Inovasi dan Teknologi Pendidikan, 7(1), 23-33.

Nindiati, D. S. (2020). Pengelolaan Pembelajaran Jarak Jauh Yang Memandirikan Siswa Dan Implikasinya Pada Pelayanan Pendidikan. JOEAI: Journal of Education and Instruction, 3(1), 14-20.

Nindiati, D. S. (2020). Pengelolaan Pembelajaran Jarak Jauh yang Memandirikan Siswa dan Implikasinya pada Pelayanan Pendidikan. JOEAI: Journal of Education and Instruction, $3(1), 14-20$.

Rifanisari, A. I., \& Badarudin, B. (2021). Penggunaan Whatsapp Group sebagai Sarana
Pembelajaran Jarak Jauh di SD Negeri TambaksarI. Khazanah Pendidikan, 15(1), 65-73.

Rozi, F., \& Lana, I. F. (2021). Implementasi Pembelajaran Jarak Jauh (PPJ) dalam Meningkatkan Kemandirian Belajar Siswa. FONDATIA, 5(1), 109-124.

Rozi, F., \& Lana, I. F. (2021). Implementasi Pembelajaran Jarak Jauh (PPJ) dalam Meningkatkan Kemandirian Belajar Siswa. FONDATIA, 5(1), 109-124

Sobri, M., Nursaptini, N., \& Novitasari, S. (2020). Mewujudkan Kemandirian Belajar Melalui Pembelajaran Berbasis Daring Diperguruan Tinggi pada Era Industri 4.0. Jurnal Pendidikan Glasser, 4(1), 64-71.

Strauss, V. (2020). 1.5 billion children around globe affected by school closure. What countries are doing to keep kids learning during pandemic. The Washington Post. Surat Edaran Menteri Pendidikan dan Kebudayaan Nomor 4 Tahun 2020 tentang Pelaksanaan Kebijakan Pendidikan dalam Masa Darurat Penyebaran Corona Virus Diseas (Jakarta, Maret 2020), 1-3.

Sudatha, I. G. W., Parmiti, D. P., \& Simamora, A. H. (2020). Pengelolaan Sumber Belajar Digital untuk Meningkatkan Pembelajaran Daring. Proceeding Senadimas Undiksha, 1585.

Sun'iyah, S. L. (2020). Media Pembelajaran Daring Berorientasi Evaluasi Pembelajaran pada Mata Pelajaran PAI di Tingkat Pendidikan Dasar. DAR EL-ILMI: Jurnal Studi Keagamaan, Pendidikan dan Humaniora, 7(1), 1-18.

Surat Edaran Kementerian Pendidikan dan Kebudayaan (Kemendikbud) dengan nomor surat 8202/C/PD/2020 tentang Program Pemberian Kuota Internet Bagi Peserta Didik, 1-6.

Sutopo, H. B. (2006). Metodologi Penelitian Kualitatif: Dasar Teori dan Terapannya dalam Penelitian. Surakarta: Universitas Sebelas Maret.

Sutrisno, S. (2021). Supervisi Klinis dengan Pendekatan Kolaboratif dalam Meningkatkan Kualitas Pembelajaran Guru di Sekolah 
Menengah Pertama. Jurnal Pendidikan Indonesia, 2(4), 744-756.

Tahar, Irzan, \& Enceng. (2006). "Hubungan Kemandirian Belajar dan Hasil Belajar pada Pendidikan Jarak Jauh", Jurnal Pendidikan Terbuka dan Jarak Jauh, 7(1), Maret: 91-101.

Tim Jurnalistik Kemendikbud. (2020). "Penyesuaian Keputusan Bersama Empat Menteri tentang Panduan Pembelajaran di Masa Pandemi COVID-19", dalam https://www.kemdikbud.go.id/main/blog/20 20/08/penyesuaian-keputusan-bersamaempat-menteri-tentang-panduanpembelajaran-di-masa-pandemi-covid19 (Diakses pada 10 Oktober 2020).

Tim jurnalistik. (2020). "Dispendik Terapkan Tiga Strategi Pembelajaran", dalam https://www.wartabromo.com/2020/10/14/d ispendik-terapkan-tiga-strategipembelajaran/ (Diakses pada 11 Oktober 2020)

Tim Penyusun. (2020). Panduan Pembelajaran Jarak Jauh: Bagi Guru selama Sekolah Tutup dan Pandemi Covid-19 dengan Semangat Merdeka Belajar. Jakarta: Kemendikbud.

Wahid, A. H., Rahman, K., Qodriyah, K., Bali, M. M. E. I., Baharun, H., \& Muali, C. (2020, July). Effectiveness of Android-Based Mathematics Learning Media Application on Student Learning Achievement. In Journal of Physics Conference Series (Vol. 1594, No. 1, p. 012047).
Wawancara dengan Arif Adinata, S.S., Waka Kurikulum MA Kholafiyah Hasaniyah, pada 10 Oktober 2020.

Wawancara dengan Arif Adinata, S.S., Waka Kurikulum MA Kholafiyah Hasaniyah, pada 10 Oktober 2020.

Wawancara dengan Eny Wahyuningsih, S.Si., guru Mapel Matematika MA Kholafiyah Hasaniyah, pada 10 Oktober 2020.

Wawancara dengan Ratri, Edy, Siswanto, siswasiswa Kelas XI MA Kholafiyah Hasaniyah, pada 11 Oktober 2020.

Wiguna, S., \& Al Qadri, M. (2021). Pengaruh Home Visit Method Terhadap Hasil Belajar Luring di Masa Pandemi COVID-19 Pada Mata Pelajaran Al Qur'an Hadits (Studi Kasus Siswa Kelas VIII MTS Jam'iyah Mahmudiyah Tanjung Pura Langkat). Continuous Education: Journal of Science and Research, 2(1), 61-71. 